\title{
"THE POINT OF JADIDISM IS CLEAR, BUT ISANBET WANTS TO CONFUSE IT IN HIS OWN WAY": FROM THE HISTORY OF THE DISCUSSION ABOUT JADIDISM IN 1950-1960-S
}

\author{
Aidar Yurievich Khabutdinov, \\ Kazan branch of Russian State University of Justice, \\ 7a, 2nd Azinzkaya Str., Kazan, 420088, Russian Federation, \\ aihabutdinov@mail.ru.
}

\begin{abstract}
The article deals with the concept of Jadidism, described in the works of the scholar-encyclopedist Naki Isanbet (1899-1992). The research is based on the writer's articles on Jadidism. Because of his views, N. Isanbet was repeatedly persecuted by the authorities in the 1930s and 1950s. The writer allowed himself an open criticism of the officially adopted concept of Jadidism. N. Isanbet's articles on Jadidism bear the evidence of the Tatar national intelligentsia's hopes for the liberalization of social and cultural life.
\end{abstract}

Key words: Tatar literature, history of the Tatars, Tatar Jadidism, Naki Isanbet, intelligentsia and power.

During the years of strict ideological dictates, Naki Isanbet openly opposed the unification of national history, which became the subject of proceedings at the highest level. In the orbit of scientists' attention were three "high-profile stories": the arrest in the "Jideghyan" case, the Resolution of the Central Committee of the All-Union Communist Party (Bolsheviks) of August 9, 1944 ("Idegey" epic), the Resolution of the Bureau of the Tatar Regional Committee of the CPSU of November 30, 1953 ("Mirkay and Aisylu", drama) ([Sultanbekov], [Tagirov], [Gosmanov], [Haplehamitov], [Khabutdinov, Khabutdinova].

Starting from 1944, N. Isanbet became famous as a writer who made "mistakes of a nationalistic nature in covering the history of Tatary" (embellishing the Golden Horde, popularizing the khanfeudal epic "Idegey"). The reason for the proceedings was not so much the epic "Idegey" as the writer's article "The $500^{\text {th }}$ Anniversary of the Tatar Folk Epic-Dastan "Idegey", which Shafikov called "erroneous" in his memo [Shafikov]. Although the name of N. Isanbet did not directly appear in the Resolution of the Central Committee of the AllUnion Communist Party (Bolsheviks) of August 9, 1944. [Postanovlenie CK VKP(b) ot 9 avgusta 1944 g.], a decades-long campaign of harassment was unleashed against him. In 1953, N. Isanbet was directly accused of defending Jadidism identifying it with enlightenment and ignoring the Resolution of the Tatar Regional Committee of the AllUnion Communist Party (Bolsheviks) "On Errors in the Literature Textbook for the 8th grade of Ta- tar Secondary Schools" of January 18, 1952. The discussion around "Mirkai and Aisylu" resulted in the adoption of the Tatar Regional Committee $\mathrm{Bu}$ reau Resolution "On Ideological Perversions in the Collection of Plays by N. Isanbet". At the Kazan city meeting of writers, composers, and theater workers on November 30, 1953, N. Isanbet was reminded that he continued to hold bourgeoisnationalist positions. At the meeting of the Board of the Union of Writers of the Tatar Autonomous Republic (TASSR), convened on February 18, 1954, G. Khalit accused N. Isanbet of misunderstanding the essence of Jadidism, and G. Bashirov accused him of confusing the issue of Jadidism "in his own way" [Haplehamitov, pp. 54-59].

The purpose of our research is to study $\mathrm{N}$. Isanbet's views on the problem of Jadidism. Our analysis is based on the archive of the writer. It contains the manuscripts of two articles on Jadidism [Isanbet, Magrifat-Jadid], [Isanbet, Jadidchelek]. Unfortunately, the manuscripts are not dated. It is obvious that they were written in the mid-1960s, because they mention the XXII Congress of the CPSU (October 17-31, 1961) and the 50th anniversary of the Great October Revolution of 1917 (1967). "Records No. 5 of the Meeting of the Board of the TASSR Union of Soviet Writers of 18.02.1954" eloquently indicates that N. Isanbet was an active participant in the discussion on Jadidism in the 1950s and 1960s. [Haplehamitov, pp. 137-142].

The historiographical analysis of the studies of Jadidism, conducted in the 1930s and 1960s, 
shows that they were politicized due to the struggle aiming to eradicate national movements and strengthen the party and state control. In the TASSR, purposeful work to expose Jadidism as a counter-revolutionary bourgeois-nationalist idea began in the late 1940s ([Mukhametov], [Revolution of 1905- 1907...], [Gainullin], [Faseev]). It reached its apogee in 1952, in the Resolution of the Tatar Regional Committee of the All-Union Communist Party (Bolsheviks) "On Errors in the Literature Textbook for the 8th Grade of Tatar Secondary Schools" of January 18, 1952, where Jadidism was declared a "bourgeois-nationalist movement" [Iz postanovleniia biuro Tatarskogo obkoma VKP (b), p. 861]. The new assessment of Jadidism was accepted behind "the closed doors" and, according to N. Isanbet, was directed "from above" to the masses, without proper discussion in the media and scientific organizations [Isanbet, Jadidchelek].

Pointing to the detailed assessment of jadidism in the first years of Soviet power, N. Isanbet refers to the work of Jamal Validi "Essays on the History of Education and Literature of the Tatars (before the Revolution of 1917)" (1923) [Validi], where jadidism was characterized as "a special kind of mental and cultural movement", the main goal of which was to approach European culture.

$\mathrm{N}$. Isanbet highlights the works of $\mathrm{G}$. Ibragimov (his articles about K. Nasiri, Sh. Marjani, the madrasah "Galiya" in Ufa) [Ibrahimov] and G. Sagdi ("History of Tatar Literature") [Sagdi] where Jadidism is characterized as a progressive phenomenon [Isanbet, Jadidchelek, p. 10].

The fire of his criticism is directed at the work of G. Gaynullin [Gainullin]. N. Isanbet describes his opponents as "comrades who deny Jadidism". The author of the article explains that while analyzing, he ignored certain available works because of their low quality: "their content is determined by low-quality vulgar sociologism, which does not stand up to any criticism". Isanbet believed that the authors of these works were poorly oriented in the history of the Tatars' public life, they resorted to falsifications, created confusion, unable to reveal the essence of Jadidism and explain who Jadids and Qadimists were. [Isanbet, Jadidchelek, pp. 29 30].

Protesting against the distortion of the history of Tatar culture, the scholar wrote a statement to the Tatar Regional Committee of the CPSU, twice met its secretary S. G. Batyev. "In its decision, the Central Committee of the Party pointed out playwright Naki Isanbet's gross political mistakes, his bourgeois-nationalist perversions of history in connection with the epic and play "Idegey". R. Ishmuratov accused $\mathrm{N}$. Isanbet of not having repented his mistakes and remaining on the same bourgeois-nationalist positions, as evidenced by his new collection of his plays".

The writer was opposed by Kavi Najmi who denounced the "nationalistic tendencies of the playwright N. Isanbet". Gazi Kashshaf could not imagine why the Tatar State Academic Theater was interested in "Mirkai and Aisylu", the play "flawed in its ideological content". The secretary of the Regional Committee of the CPSU S. Batyev reminded everyone that "the decision of the Central Committee of the Party of 1944 is a program document for all writers and, generally, for art workers in Tatarstan". In his speech, he expanded and specified the charges against N. Isanbet. The Republican authorities expressed dissatisfaction with the writer's assessment of Jadidism and accused him of trying to "push nationalist ideas through the replicas of his characters". The conflict broke out because of the way one of the characters addressed the villagers: "Muselman-kardeshlar" ("Muslim brothers"). S. Batyev described it as the slogan of the nationalists. The Secretary of the Regional Committee of the CPSU expressed dissatisfaction with $\mathrm{N}$. Isanbet's assessment of Sh. Marjani's personality. He was outraged that the "reactionary figure" was described in the work as an educator (See: [Haplehamitov, p. 143]).

After the scandal in 1953, with the publication of the drama "Mirkai and Aisylu", the writer was forced to seek "truth" and protection in Moscow. He wrote a letter to N. S. Khrushchev and obtained the cancellation of the Resolution of the Bureau of the Tatar Regional Committee "on ideological perversions in the collection of plays by N. Isanbet" (November, 1953).

$\mathrm{N}$. Isanbet's articles on Jadidism reflected the hopes of the Soviet society for the continuation of de-Stalinization course, for the return of the Tatar culture former richness. The scholar opposed a wave of falsifications by official scientists in the name of discrediting Jadidism: "In the first essay, it was separated from enlightenment. Further on they claimed that Jadidism was a purely bourgeois movement, born in the era of imperialism, its content appeared to be pan-Islamism and panTurkism, and the Enlightenment was a revolutionary - democratic movement that was not compatible with any other, like a child and water." To prove this far-fetched thesis, all representatives of 
the revolutionary democracy ${ }^{1}$, (although these representatives in most cases called themselves Jadids) were forcibly called enlighteners, all reactionary elements were called Jadids" [Isanbet, Jadidchelek, p. 4]. The scholar was outraged by the ignoring of the opinions of Tatar intelligentsia who, starting with Tukai and Gafuri, had declared themselves to be Jadids or disciples of Jadid madrasahs (G. Ibragimov, G. Kamal, Sh. Kamal, F. Burnash, Sh. Ahmadiev, K. Tinchurin, F. Saifi, M. Faizi, Khadi Taktash, Kh. Tufan, Musa Jalil, M. Maksud, A. Faizi, etc.).

Reflecting on the history of this term's existence in the Tatar world, N. Isanbet stated: "New Jadid, Jadid method, stands for the "method of sounds". This word was actively used in the 1890s to refer to teaching in the native language based on the method of sounds based on the new alphabet after the rejection of the syllabic method, accepted for teaching literacy in old Tatar schools, which was based on the Arabic alphabet. As a result, this word is used in a broader context, it has become associated with the introduction of new subjects in primary education to mean new methods of teaching in maktabs and madrasahs in the sense of cultural modernization, Europeanization and Jadid renewal. They replaced the teaching of religious scholasticism. That is why the leaders of this movement and its participants were called Jadids, and those who conducted training and education in maktabs and madrasahs based on medieval methods - Qadimists [Isanbat, Jadidchelek, p. 6-7].

$\mathrm{N}$. Isanbet defended the idea of national identity of Tatar Jadidism, which was born amidst the bourgeoisie. The scholar considered it wrong to relate this movement, due to differences in social life, with the French, German and Russian Enlightenment. In his opinion, the Tatar jadids, advocating the modernization of Tatar culture and education, waged an irreconcilable struggle with Qadimism, whose representatives were the conductors of medieval religious fanaticism and backwardness [Isanbet, Jadidchelek, p. 8].

$\mathrm{N}$. Isanbet saw the distinguishing feature of Tatar Jadidism to be the national education system of the Tatars, which was not controlled or funded by the state. In view of this, the issue of education became the foundation for the development of a new social movement and the formation of a new social ideology. All hopes for progress in the sciences, renewal of culture, and national freedom attain-

\footnotetext{
${ }^{1}$ See the works of Muhammad Gainullin.
}

ment among the Tatars, regardless of who owned the school, were pinned on jadidism.

$\mathrm{N}$. Isanbet believed that Jadidism could not be separated from Enlightenment. Among the Tatar people, it was customary to use them as synonymous words.

In his articles, N. Isanbet polemized with $\mathrm{M}$. Gainullin, who identified the "revolutionary democratic movement" of Jadidism with the "harmful ideology", i.e. pan-Turkism and pan-Islamism and saw the only difference between the liberals and qadimists in the fact that they formerly represented the interests of the national bourgeoisie [Gainullin, p.16]. He was particularly angered by the transformation of Sh. Marjani into a bourgeois-liberal ideologue [Gainullin, p. 11].

In an effort to restore historical justice, $\mathrm{N}$. Isanbet consistently broke down all the accusations made against jadidism in the 1940s and 1950s. The scholar was sincerely outraged that the disputes between the Jadids and Qadimists were characterized as those of a "fussy mouse", started by the national bourgeoisie out of idleness. N. Isanbet insisted that the representatives of various strata of the Tatar people, focused on progress, opposed the ideology of Qadimism.

The scholar described the enthusiasm with which Tatar youth took up the task of modernizing Tatar education and culture in the wake of the national consciousness rise: "As you know, Tatar youth rushed to this platform of opportunities, if it was not there, they created it themselves. In the course of this activity, its representatives revealed their talents and abilities. Some of them became teachers, others started writing research papers and textbooks, worked in newspapers and became writers.

There was a suitable occupation for everyone" [Isanbet, Magrifat-Jadid, p. 34].

According to the scholar, the differences between Qadimists and Jadids could not be reduced to differences in their manner of dress. It was a struggle between the new and the old. Qadimists were the bearers of feudal ideology, saw madrasahs as institutions to trains mullahs and muazzins, they conducted agricultural activities in the old way, took advantage of the backwardness of the people. That is why representatives of various strata of society, who lived with the idea of the Motherland, treated their people with love, were focused on progress and education, joined the fight against them.

$\mathrm{N}$. Isanbet identified two stages in the development of Tatar Jadidism. During the first stage, 
from the end of the $19^{\text {th }}$ century until 1905 , this movement had a bourgeois-educational character and was brought to life by the growth of national consciousness. The core of the movement was teachers who were educated abroad or educated in Russia, progressive mullahs and merchants- sponsors. Their efforts resulted in the reform of the national education system.

The second stage came after the 1905 Revolution, when Jadidism, having got rid of spontaneity became a powerful mass social movement under the leadership of "Islahists" ("Islah" means reform in Arabic), representatives of the revolutionarydemocratic youth. At this stage, the Jadids expressed their dissatisfaction with reality through revolutionary strikes and collective withdrawal from madrasahs. The researcher believes that by 1917, the Jadid movement had come to naught, since control over the education system was completely realized by the state and education became secular.

Among the opponents of Jadidism, N. Isanbet referred to Ishmi-ishan (Dinmukhametov) and his associates, Tatar provocateurs-the blackhundredists, by scribbling denunciations, provoked the authorities to start pogroms in Jadid madrasahs under the slogan of fighting pan-Turkism.

$\mathrm{N}$. Isanbet believed that as a result of the reform, the Jadid madrasahs became a place for training the Tatar national intelligentsia. In his book, with reference to S. Kudash, he gives an illustrative section on the issues of the "Galiya" madrasah: "In 1906-1919, 1500 shakirds graduated from the "Galiya" madrasah in 13 years, only 27 of them became mullahs. Of the 100 people (according to F. Sayfi), 57 became members of the CPSU, 20-professional writers, representatives of socialist realism, 28-journalists, editors of frontline newspapers, 58-professors, candidates and doctors of science, 6-agronomists, 3-engineers, 3lawyers, 4-diplomats, 6-Tatar and Bashkir Ministers of Education, 2-artists, 1-composer, and others became teachers". [Isanbet, Magrifat-Jadid, p. 39].

$\mathrm{N}$. Isanbet protestsed against the use of vulgar sociological formulations in evaluating Tatar jadidism. The scholar analyzed and proved the inconsistency of a number of accusations made against jadidism:

a) connection with pan-Turkism.

For Jadidism the political problem was created by the personality of its founding father, Ismail Gasprinsky, primarily, a representative of the Crimean Tatar ethnic group, who was deported from his homeland in 1944 and was partially rehabilitat- ed only in 1967. In the post-war period, the USSR maintained traditionally hostile relations with Turkey, where many of the representatives of jadidism were educated.

The Tatar scholar, trying to smooth over "rough edges" insisted that the origins of the renewal of the national education system were primarily Tatar scientists-educators: G. Kursavi, Khalfins, Sh. Marjani, K. Nasyri, the Faizkhanov brothers who took up the reform of Tatar madrasahs, not I. Gasprinsky. [Isanbet, Jadidchelek, pp. 15-16]. N. Isanbet emphasized that $M$. Ishmukhammetov and G. Barudi, the creators of the Tatar alphabet, focused more on the European experience, in particular, on the achievements of K. D. Ushinsky rather than the alphabet of I. Gasprinsky when introducing the "method of sounds". The researcher characterizes I. Gasprinsky as the editor of the newspaper "Tarjeman" ("The Interpreter"), who dreamt of the unity of the Turks based on the unity of the language. According to the scholar, Tatar scientistseducators: Marjani, Faizkhanov, Nasyri, etc., from the 1880s created projects and published books aimed at reforming the national education system on the model of Russian high schools and universities. In fact, they generated ideas of Tatarism, not Turkism.

Qadimists fought fiercely with the European knowledge, in the belief that it would lead a person to becoming "a kafir" (an apostate of the Muslim faith) and to Russification [Isanbet, MagrifatJadid, pp. 56-61].

b) the charge of pan-Islamism.

According to N. Isanbet, Jadidism as a cultural and educational movement has a century-old history and has nothing to do with the "Ittifak almuslimin" liberal party, created in 1905 and consisting of Muslim cadets from among the landlords and the large bourgeoisie whose activities came to naught during the reaction that came after the defeat of the revolution of 1905-1907. [Isanbet, Jadidchelek, pp. 17-18]

The scholar emphasized that after 1905, the Jadid movement was controlled by the representatives of the social democratic party in the person of Kh. Yamashev, G. Kulakhmetov and others. Later, they represented various parties: left-wing social Democrats (the "Uralchilar"), right-wing social democrats (the "Azatchilar"), and socialistrevolutionaries (the "Tanchilar"). Having created the "Islah" Committee, representatives of advanced Tatar youth exercised control over the network of madrasahs. They organized revolutionary strikes 
and the strikes of shakirds, created radical periodicals in the Tatar language: newspaper "Fiker" ("The Idea"), magazines "Yashen" ("Lightning"), "Karchiga" ("Hawk"), "Chukech" ("Hammer"). N. Isanbet believed that they successfully fought against the "Ittifak al-muslimin" [[Isanbet, Magrifat-Jadid, p. 45]. Writers G. Tukay, M. Gafuri, F. Amirkhan, G. Kulakhmetov, and G. Ibragimov, who declared themselves Jadids, made a huge contribution to the development of Tatar literature of realism. N. Isanbet emphasized the role of the Jadids in the formation of the national press when after the October revolution, graduates of Jadid schools joined the ranks of political agitators, commissars of the Red Army, and became the creators of front-line newspapers.

Denying the connection of Tatar Jadidism with pan-Islamism, N. Isanbet pointed to a number of works of Tatar writers who openly criticized this phenomenon (G. Tukay "Kitmibez" "“We Will Not Leave"),"Vakyt" ("Time"); G. Ibragimov "Bez Tatarbiz" ("We Are Tatars")), which indicates the continuity of ideas of Tatarism among the Tatar people, whose ancestors appeared to be enlighteners Marjani and Nasiri [Isanbet, Magrifat-Jadid, pp. 46-61]. The Tatar scholar drew attention to the fact that the connection of Jadidism with panIslamism and pan-Turkism was not proved even in the course of the trials initiated by Ismi-Ishan and his supporters [Isanbet, Magrifat-Jadid, p. 50].

c) "Jadidism - counter-revolutionary movement".

$\mathrm{N}$. Isanbet strongly opposed the division of jadidism into two wings, imposed "from above". Polemizing with B. G. Gafurov [Gafurov] and his associates, the Tatar scientist insisted that Tatar Jadidism was a cultural and educational movement aimed at reforming education based on the European model and modernization of Tatar literature and culture. The Tatar scholar believed that, due to its inconsistency, the concept of "Arakcheevshina", imposed "from above", would cause significant damage to the national education system, because it helped to create a false picture of what had happened in the national culture during the period of Jadidism.

N. Isanbet opposed Tatar scientists' blind copying of accusatory "labels" used in the analysis of Central Asian Jadidism.

As a scholar-encyclopedist, he opposed falsification of national history and disregard of the cultural potential of the past. He insisted on the need to overcome the ideological mistakes made during the personality cult, which contradicted Lenin's national policy.

$\mathrm{N}$. Isanbet's articles on the problem of jadidism are an important source for studying the history of this cultural and educational movement in the history of the Tatars. This is evidence of the hopes of the national intelligentsia for the liberalization of social and cultural life. The analysis of available materials shows that $\mathrm{N}$. Isanbet was an active participant in the discussion on Jadidism, he dared to go against the officially approved point of view in the conditions of the strict party control. In his articles, the Tatar scholar-encyclopedist examined the prerequisites for the development of Jadidism, briefly described the features of two stages in its development, outlined the national identity of this cultural and educational movement, broke down the shaft of falsifications aimed at discrediting Jadidism as a phenomenon. N. Isanbet's active participation in the discussion on jadidism is clear evidence of his bold civic position.

\section{References}

Gafurov, B. G. (1958). Uspekhi nacional'noj politiki KPSS $i$ nekotorye voprosy internacional'nogo vospitaniya [Successes of the National Policy of the CPSU and Some Issues of International Education]. Kommunist. No. 11. (In Russian)

Gainullin, M. Kh. (1955). Kaium Nasyrov $i$ prosvetitel'skoe dvizhenie sredi tatar. [Kayum Nasyrov and the Educational Movement among the Tatars]. $96 \mathrm{p}$. Kazan, Tatknigoizdat. (In Russian)

Gosmanov, M. (2019). Aksakallar mailesennan. Naki Isanbet (1899-1992) [From the Majlis of the Elders. Naki Isanbet (1899-1992)]. Həter mizgelləre: istəleklər. Pp. 174-199. Kazan, Tatar. kit.nəshr. (In Tatar)

Haplehamitov, R. B. (2011). Tatarskaia tvorcheskaia intelligentsiia $i$ vlast' (1944-1965) [Tatar Creative Intelligentsia and Authorities (1944-1965)]. 152 p. Kazan, Slovo. (In Russian)

Faseev, K. F. (1955). Iz istorii tatarskoi peredovoi obshchestvennoj mysli. (Vtoraya polovina XIX - nachalo $X X$ v.) [From the History of Tatar Advanced Social Thought. (The second half of the $19^{\text {th }}$ - early $20^{\text {th }}$ centuries)]. 280 p. Kazan', Tatknigoizdat, Red. polit. i ist. lit. (In Russian)

Ibrahimov, G. (1915). Buek ostazymyznyn kaiber taaliflare [Several Works of Our Great Teacher]. Ang. No. 1. pp. 7-19. (In Tatar)

Isanbet, N. Magrifat-Jadid [The Enlightment Jadid]. The personal archive of N. Isanbet, a manuscript, 40 pages. (In Tatar)

Isanbet, N. Jadidchelek [Jadidism]. The personal archive of N. Isanbet, manuscript, 20 pages, not dated. (In Tatar)

Iz postanovleniia biuro Tatarskogo obkoma VKP

(b) "Ob oshibkah $v$ uchebnike literatury dlia 8 klassa 
tatarskih shkol" (2013) [From the Resolution of the Tatar Regional Committee of the All-Union Communist Party (Bolsheviks) "On Errors in the Literature Textbook for the 8th Grade of Tatar Secondary Schools" of January 18, 1952]. Istoriia tatar s drevneishih vremen: 7 t. T. 7, pp. 861-862. Kazan', Institut istorii Sh. Mardzhani AN RT, (In Russian)

Khabutdinov, A., Khabutdinova, M. (2019). Obraz Naki Isanbeta $v$ tatarskoi proze [The Image of Naki Isanbet in Tatar Prose]. Philology and Culture. No. 4(58), pp.191-201. (In Russian)

Mukhametov, Kh. G. (1953). Prosvetitel'skie idei v tatarskoi literature poslednei chetverti XIX veka. Avtoref. dis. ... kand. filolog. nauk [The Enlightenment Ideas in Tatar Literature of the Late $19^{\text {th }}$ Century: Ph.D. Thesis Abstract]. Kazan', KGU, 17 p. (In Russian)

Postanovlenie CK VKP(b) ot 9 avgusta 1944 g. "O sostoianii $i$ merah uluchsheniia massovo-politicheskoi $i$ ideologicheskoi raboty $v$ Tatarskoi partiinoi orgvnizatsii" (1985). [Resolution of the Central Committee of the All-Union Communist Party (Bolsheviks) of August 9, 1944]. KPSS v rezolyutsiiah i resheniiah s'ezdov i plenumov CK v 16 t. - t.7. (1938- 1945). Pp. 13 - 520. Moscow, Politizdat. (In Russian)
Revoliutsia 1905-1907 gg. v natsional'nyh raionah Rossii: Sbornik statei (1955) [Revolution of 1905-1907 in the National Regions of Russia: A Collection of Articles]. Pod red. L. M. Ivanova [i dr.] ; Akad. nauk SSSR. In-t istorii. 832 p. Moskva, Gospolitizdat. (In Russian)

Sagdi, G. (1926). Tatar adabiiati tarihi [The History of Tatar Literature]. 300 p. Kazan, Tatar. Devlet nəshr. Basmasi. (In Tatar)

Shafikov K. (1944). Tarihi chynlyk uchen [For the Historical Truth]. Sovet adabiyati. No. 10, pp. 3-8. (In Tatar)

Sultanbekov, B. (1992). "Idegey”, Stalin i nashe vremia ["Idegey", Stalin and Our Time]. Tatarstan, No. 7-8, pp. 32-47. (In Russian)

Tagirov, I. R. (1993). Altyn Urda hom "Idegei" dastany [The Golden Horde and "Idegey" Epic]. Kazan utlary. No. 11, pp. 145-147. (In Tatar)

Validov, J. (1923). Ocherk istorii obrazovannosti $i$ literatury tatar (do revolyutsii $1917 \mathrm{~g}$.). [Essays on the History of Education and Literature of the Tatars (before the Revolution of 1917)]. 106 p. Moskva; Petrograd, Gos. izd-vo. (In Russian)

\title{
«ЖӘДИТЧЕЛЕК МӘСЬӘЛӘСЕ ИНДЕ ХӘЛ ИТЕЛГӘН, ЛӘКИН ИСӘНБӘТ АНЫ ҮЗЕНЧӘ БУТАРГА ТЕЛИ»: 1950-1960 ЕЛЛАРДАГЫ ЖӘДИТЧЕЛЕК ТУРЫНДАГЫ БӘХӘСЛӘРДӘН
}

\author{
Айдар Юрьевич Хәбетдинов, \\ Россия гадел хөкем университетының Казан филиалы, \\ Россия, 420088, Казан ш., 2 нче Азин урамы, 7а йорт, \\ aihabutdinov@mail.ru.
}

\begin{abstract}
Мәкаләдә энциклопедист галим Нәкый Исәнбәтнең (1899-1992) хезмәтләрендә яктыртылган концепция тасвирлана. Эзләнү материалы булып, язучының жәдитчелеккә багышланган мәкаләләре тора. 1930-1950 нче елларда үзенең карашлары аркасында Н. Исәнбәт күп тапкырлар хакимият тарафыннан төрле эзәрлекләүләргә дучар ителә. Язучы өстән төшерелгән жәдитчелек концепциясен ачык тәнкыйть итүдән дә курыкмый. Н. Исәнбәтнең жәдитчелек турындагы мәкаләләре - милләт зыялыларының ижтимагый-мәдәни тормышны либерализацияләү турындагы өметләре ул.
\end{abstract}

Төп төшенчәләр: татар әдәбияты, татар халкы тарихы, татар жәдитчелеге, Нәкый Исәнбәт, зыялылар, интеллигенция һәм хакимият.

Катгый идеологик контроль елларында Нәкый Исәнбәт берничә тапкыр милли тарихны бердәйләштерү, бердәм нормага китерүгә, ягъни унификациягә каршы чыга. Галимнең бу каршы фикере исә иң югары дәрәжәдәге тикшерүләргә дучар ителә. Галимнәр игътибарының үзәгенә аның тормышындагы өч «дөнья шаулаткан тарих»: «Жидегән» эшчәнлеге белән бәйле кулга алыну, ВКПб Үзәк комитетының 1944 елның 9 августы «Идегәй» эпосы турындагы карары, КПСС Татар өлкә комитеты бюросының 1953 елның 30 ноябрендәге «Миркәй һәм Айсылу» карары куела [Султанбеков], [Тагиров], [Госманов], [Хаплехамитов], [Хабутдинова].

1944 елдан Н. Исәнбәтне «Татар АССР тарихын сурәтләүдә милли характердагы хаталар жибәрүче» (Алтын Урданы бизәкләп, чуарлап күрсәтүче, «Идегәй» хан-феодал эпосын популярлаштыручы) язучы итеп бәяли 
башлыйлар. Тикшерүләргә сәбәп булып, «Идегәй» эпосыннан бигрәк, язучының «Татар халык «Идегәй» эпос-дастанының 500 еллыгы» дигән мәкаләсе тора. Бу мәкаләне Шафиков үзенең доклад язуында «ялгыш, хата» дип атый [Шафиков]. ВКП(б) Үзәк комитетының 1944 елның 9 августы карарында [Постановление ЦК ВКП(б) от 9 августа 1944 г.] Н. Исәнбәт исеме турыдан-туры телгә алынмаса да, язучы дистәләрчә елларга сузылган эзәрлекләүләргә дучар була.

1953 елда Н. Исәнбәтне жәдитчелекне яклауда, аны мәгърифәтчелек белән тәңгәлләштерүдә, шулай ук ВКП(б) Татар өлкә комитетының «Татар урта мәктәпләренең 8 сыйныф әдәбият дәреслегендәге хаталар» турындагы карарын игьтибарсыз калдыруында гаеплиләр. «Миркәй һәм Айсылу» әсәре тирәсендәге бәхәсләр исә Татар өлкә комитеты бюросының «Н. Исәнбәтнең пьесалар жыентыгындагы идеологик бозыклыклар» дигән карар кабул итүенә китерә. 1953 елның 30 ноябрендәге язучылар, композиторлар һәм театр хезмәткәрләренең шәһәр жыелышында язучының һаман да буржуаз-милләтче позициясендә кала бирүен исенә төшерәләр. 1954 елның 18 февралендә ТАССР Язучылар Союзы идарә утырышында $Г$. Халит $H$. Исәнбәтне жәдитчелекнең асылын аңламауда, ә Г. Бәширов жәдитчелек мәсьәләсен «үзенчә» буташтыруда гаепли [Хаплехамитов, С. 54-59].

Тикшеренүебезнең максаты - Н. Исәнбәтнең жәдитчелек мәсьәләсенә булган карашларын өйрәнү. Анализланачак материал ролен язучы архивында саклана торган 2 мәкалә кулъязмасы үти [Исәнбәт, Мәгърифәт-жәдид], [Исәнбәт, Жәдитчелек]. Кызганыч, кулъязмаларның язылу вакыты күрсәтелмәгән. Шулай да аларның 1960 нчы еллар уртасында язылганлыгын фаразлап була, чөнки мәкаләләрдә КПСС ның XXII съезды (1961 елның 17-31 октябре) hәм 1917 елгы Бөек Октябрь революциясенең 50 еллыгы (1967) телгә алына. «ТАССР совет язучылар берлеге идарәсе утырышының (18.02.1954) 5 номерлы протоколы» Н. Исәнбәтнең жәдитчелек турындагы 1950 - 1960 еллардагы бәхәсләрнең актив катнашучысы булуын дәлилли [Хаплехамитов, C. 137-142].

Жәдитчелеккә багышланган 1930 - 1960 елгы тикшеренүләргә историографик анализ аларның сәясәтләштерүгә дучар ителүләрен, моның исә Үз чиратында милли хәрәкәтләрне юкка чыгару hәм партия-дәүләт контролен көчәйтүгә юнәлгән көрәш белән бәйле булуын дәлилли. ТАССР да жәдитчелекнең контрреволюцион буржуаз-милли агым «булуын» фаш итүгә юнәлтелгән хәрәкәт 1940 елның ахырында башланып китә [Мухаметов], [Революция 1905-1907...], [Гайнуллин], [Фасеев]. Иң югары ноктасына ул 1952 елда житә, бу вакытта ВКП(б) Татар өлкә комитеты бюросының «Татар урта мәктәпләренең 8 сыйныф әдәбият дәреслегендәге хаталар» турындагы карарына (1952 елның 18 гыйнвары) кул куела, һәм жәдитчелек «буржуаз-милли хәрәкәт» дип бәяләнә [Из постановления, С. 861]. Жәдитчелекнең яңа билгеләмәсе «ябык ишекләр» артында кабул ителә һәм, Н. Исәнбәт фикеренчә, «өстән» массаларга төшерелә, массакүләм мәгьлүмат чараларында hәм гыйльми оешмаларда фикер алышмыйча, көчләп тагыла. [Исәнбәт, Жәдитчелек, Б. 28].

Үз мәкаләләрендә Н. Исәнбәт жәдитчелек мәсьәләсенә багышланган фәнни әдәбиятка анализ ясамый диярлек. Совет хакимиятенең беренче елларында жәдитчелеккә бирелгән тәфсилле бәягә ишарәләгәндә, мәкалә авторы Жамал Вәлидинең «Очерки истории образованности и литературы татар (до революции 1917 г.)» (1923) [Валиди] хезмәтен күздә тота булса кирәк. Анда жәдитчелек төп максаты Европа мәдәнияте белән якынаю булган «үзенчәлекле акыл-мәдәният хәрәкәте буларак» тасвирлана. Бигрәк тә Н. Исәнбәт жәдитчелекне прогрессив күренеш итеп сурәтләгән Г. Ибраһимов (К. Насыйри, Ш. Мәржани, «Галия» мәдрәсәсе турындагы мәкаләләр) hәм Г. Сәгъди («Татар әдәбияты тарихы») хезмәтләрен аерып күрсәтә [Исәнбәт, Жәдидчелек, Б.10]. Ул Г. Гайнуллин хезмәтен нык тәнкыйть утына сала [Гайнуллин]. Оппонентларын Н. Исәнбәт исә «жәдитчелекне инкяр итүче иптәшләр» дип атый. Анализ ясау вакытында башка хезмәтләргә игътибар итмәүләрен, ул аларның түбән сыйфатлы булулары белән аңлата: «алар шулкадәр түбән сорт вульгар социологизмнан гыйбарәт, бернинди тәнкыйтьне дә күтәрерлек түгел». Н. Исәнбәт фикеренчә, бу хезмәтләрнең авторлары «үзләре хәл итәргә алган жәдитчелекмәгърифәтчелек хәрәкәтенең асылын да, затын да, аны урын ягыннан да, заман ягыннан да, аның милли составын да, сыйфый-ижтимагый тенденцияләрен дә, кемгә каршы юнәлүен дә, жәдите дә, кадиме дә, кыскасы, бер генә моментын да дөрес ачыклый алмыйлар. Берсе хакында да бер генә (30) дөрес мәгълүмат та 
бирә алмыйлар» [Исәнбәт, Жәдитчелек, С.2930].

Татар мәдәнияте тарихын бозып сурәтләүгә каршы килеп, галим КПСС ның Татар өлкә комитетына гариза яза, ике тапкыр обком секретаре С.Г. Батыев белән күрешә. «Партия Үзәк комитеты Үз карарында Н. Исәнбәтнең тупас сәяси хаталарына, аның «Идегәй» пьесасы белән бәйле тарихны сурәтләүдәге буржуаз-милләтчел бозыклыкларына төртеп күрсәтә. Р. Ишморатов Н. Исәнбәтне Үз хаталарын танымауда һәм элеккечә буржуазмилләтчел позициядә калуында гаепли, бу хакта аның яңа пьесалар жыентыгы хәбәр итә, дип саный».

Язучыга каршы Кави Нәжми чыгыш ясый. Ул «драматург Н. Исәнбәтнең милләтчел тенденцияләрен» кискен тәнкыйть итә. Гази Кашшаф исә «эчтәлеге белән бозык булган» «Миркәй һәм Айсылу» пьесасының Татар дәүләт академия театрын кызыксындыруына аптырый. КПСС өлкә комитеты секретаре С. Батыев «партия Үзәк комитетының 1944 елгы карарының барлык язучылар һәм, гомумән, ТАССР мәдәният хезмәткәрләре өчен программа документы булуын» һәркемнең исенә төшерергә тырыша. Үз чыгышында ул Н. Исәнбәткә булган гаепләмәләрен киңәйтә һәм төгәлләштерә. Республика хакимияте язучының жәдитчелеккә биргән бәясе белән канәгать булмавын белдерә һәм аны «милләтчел идеяләрне геройларының репликалары аша үткәрергә» тырышуда гаепли. Шау-шу әсәрдәге бер геройның авылдашларына «мөселман кардәшләр» дип эндәшүеннән соң башлана. C. Батыев бу эндәшүне милләтчеләрнең лозунгы буларак бәяли. КПСС өлкә комитеты секретаре Н. Исәнбәтнең Ш. Мәржани шәхесен бәяләае белән дә канәтьсез кала. Аңа «реакционер»ның мәкаләдә мәгърифәтче буларак сурәтләнүе ошамый (тулырак [Хаплехамитов]). 1953 елда «Миркәй һәм Айсылу» драмасын нәшер итү белән бәйле гаугадан соң, язучы «хакыйкать» hәм яклау эзләп, Мәскәүгә мөрәжәгать итә.Ул Н. С. Хрущёвка гариза яза һәм «Н. Исәнбәтнең пьесалар жыентыгындагы идеологик бозыклыклар» дигән карарны (ноябрь, 1953) кире кагуга ирешә.

H. Исәнбәтнең жәдитчелек турындагы мәкаләләрендә совет жәмгыятенең десталинизация курсын дәвам итү, татар мәдәниятенең элекке кыйммәтен кайтару чагылыш таба. Галим жәдитчелеккә дискредитация ясарга омтылган партия галимнәренең күпләгән ялганнарына, фальсификацияләренә каршы чыга: «Иң элек аны мәгърифәтчелектән аералар. Аннары, жәдитчелек ул империализм чорында туган саф буржуаз хәрәкәт, аның эчтәлеге, менә күрәсез, панисламизм һəм пантюркизмнан гыйбарәт, ә мәгьрифәтчелек исә ул революцион-демократик /?/ хәрәкәт ${ }^{1}$, бу нәрсәләр, ут белән су кебек, бер-берсе белән сыеша алмый, диләр. һәм шул ясалма тезисны исбатлау өчен, татар ижтимагый тарихындагы барлык революцион демократия вәкилләрен /гәрчә бу вәкилләр күпчелек очракта үзләрен жәдитче дип кычкырып торсалар да/ барын да көчләп мәгърифәтчеләр дип атап, калган барлык реакцион элементларны жәдитчеләр дип исемлиләр» [Исәнбәт, Жәдитчелек, Б.4 ]. Галим татар зыялыларының, үзләрен әллә кайчан жәдитчеләр дип игълан иткән язучылар (М. Гафури, Г. Ибраһимов, Г. Камал, Ш. Камал, Ф. Бурнаш, Ш. Әхмәдиев, К. Тинчурин, Ф. Сәйфи, М. Фәйзи, һ. Такташ, Х. Туфан, М. Жәлил, М. Максуд, Ә. Фәйзи һ.б.) фикерләренең игътибарсыз калуына да ачулана.

Бу терминның татар дөньясында яшәу тарихы турында уйланып, Н. Исәнбәт болай яза: «Жәдит - яңа, ысулы жәдит - яңа метод дигән сүз. Бу сүз башта 1890 нчы елларда элекке иске татар мәктәпләрендә ижек ысулы белән гарәп әлифбие, укуны ташлап, ана телендә аваз методы яңа әлифба буенча уку дигән мәгънәдә тормышка куллануга кереп киткән. Шуннан бу сүз киңрәк мәгънә хасыйл итеп, гомумән, мәктәп-мәдрәсәләрдә дини схоластика уку урынына, ана телендә башлангыч фәннәр кертү һем уку методларын Үзгәртү, гомумән тормышта, культуралашу, европалашу мәгънәсендә жәдитләшү /яңару/ дигәнне аңлатып киткән. Менә шуннан бу хәрәкәтне алып баручылар да жәдитчеләр дә элекке урта гасыр методлары белән тормыш һәм мәктәп-тәрбия эшләрен алып баручылар да кадимчеләр дип аталганнар». [Исәнбәт, Жәдитчелек, Б. 6-7].

Н. Исәнбәт буржуазия мохитендә туган татар жәдитчелегенең милли үзенчәлеге идеясен хуплый. Галим фикеренчә, бу хәрәкәтне, ижтимагый hәм социаль тормыштагы аермаларга бәйле, француз, алман мәгарифе hәм рус мәгърифәтчелеге белән тәңгәлләштерү дөрес түгел дип уйлый. Аның фикеренчә, татар жәдитчеләре, татар мәдәнияте hәм мәгърифәтен яңартырга, модернизация-

\footnotetext{
${ }^{1}$ Мәсәлән, Гайнуллин хезмәтләре каралсын.
} 
ләргә теләп, урта гасыр дини фанатизм һәм артта калганлык тарафдарларыннан торган кадимчелек белән көрәш алып бара [Исәнбәт, Жәдитчелек, Б. 8].

Татар жәдитчелегенең үзенчәлеген $\mathrm{H}$. Исәнбәт татарларда милли мәгариф системасының дәүләт тарафыннан контрольдә тотылмавында һәм матди яктан тәэмин ителмәүдә күрә. Шуна күрә мәгърифәт мәсьәләсе яңа ижтимагый хәрәкәт барлыкка килү һәм яңа ижтимагый идея формалашу өчен, нигез булып тора. Фәннәрдә прогресска ирешү, мәдәниятне яңарту, татар халкының милли иреккә ирешү турындагы өметләре, мәктәп кемнеке генә булса да, жәдитчелеккә юнәлдерә.

H. Исәнбәт фикеренчә, жәдитчелекне мәгърифәтчелектән аерып карарга ярамый. Татар халкы мохитендә әлеге сүзләр синонимнар буларак кулланыла.

Мәкаләләрендә Н. Исәнбәт «революцион демократик хәрәкәт» - жәдитчелекне «зарарлы идеология» - пантюркизм һәм панисламизм белән тиңләштергән hәм либералларның кадимчеләрдән бердәнбер аермасын бары тик аларның милли буржуазия ихтыяжларын кайгыртуында күргән M. Гайнуллин белән бәхәсләшә [Гайнуллин, С. 16]. Мәржанине буржуаз-либераль идеолог дип сурәтләгән положение аңа бигрәк тә ошамый [Гайнуллин, С. 11].

Тарихи гаделлекне торгызырга тырышып, Н. Исәнбәт 1940-1950 елларда жәдитчелеккә каршы күтәрелгән барлык гаепләмәләрне бербер артлы кире кага. Галим жәдитчеләр һәм кадимчеләр арасындагы бәхәсләрне кирәксез бер эш, эшсезлектән интеккән милли буржуазия уйланмасы дип санаучыларны кискен тәнкыйтьли. Н. Исәнбәт прогресска юнәлеш тоткан татар халкының төрле катлам вәкилләре кадимчелек идеологиясенә каршы чыгыш ясый дип белдерә. Татар яшьләренең милли үзаң күтәрелеше дулкынында татар мәгърифәтен hәм мәдәниятен яңартырга омтылуын болай сурәтли: «һәм, билгеле, татар яшьләре шул мөмкинлекләр мәйданына атылалар, мәйданы булмаса, анысын да үзләре ясыйлар. Шул мөмкинлекләр юлында үзләренең талантсәләтләрен ача башлыйлар. Берләре - укуукытучы педагог, икенчеләре гыйльми-фәнни әсәрләр, дәреслекләр яза, өченчеләре -әдәбиятматбугат кешеләре. һәркемгә эш». [Исәнбәт, Мәгърифәт - Жәдид, Б. 34].

Галим фикенчә, кадимчеләр һәм жәдитчеләр арасындагы аерманы аларның киенү рәвешенә генә кайтарып калдырырга ярамый. Бу иске белән яңа көрәше була. Феодаль идеология тарафдарлары булган кадимчеләр мәдрәсәне мулла-мөэзиннәр әзерләү урыны дип күрә, хужалык эшчәнлеген искечә алып бара, халыкның артта калганлыгыннан файдалана. Менә шуңа күрә алар белән көрәшкә Ватаннары турында уйлаган, халкын яраткан, прогресс һәм мәгърифәтчелеккә омтылган төрле катлам вәкилләре күтәрелә.

Н. Исәнбәт татар жәдитчелеге үсешендә ике этапны аерып чыгара. Беренче этапта (XIX гасыр ахыры - 1905 ел) бу хәрәкәт буржуазмәгърифәтчел хәрәкәт төсен ала һәм милли үзаң үсеше нәтижәсендә барлыкка килә. Хәрәкәтнең нигезен чит илдә яисә рус телендә белем алган укытучы-мөгаллимнәр, алдынгы карашлы муллалар һәм химаяче сәүдәгәрләр тәшкил итә. Алар тырышуының нәтижәсе булып милли мәгариф системасының реформасы тора.

Икенче этап 1905 ел инкыйлабыннан соң башлана. Бу вакытта жәдитчелек, агым буенча баруыннан котылып, «ислахчы»лар - революцион-демократик яшьләр житәкчелегендә көчле массакүләм ижтимагый хәрәкәткә әверелә. Бу этапта жәдитчеләр чынбарлыктан канәгатьсез булуларын революцион характердагы эш ташлаулар, бергәләшеп мәдрәсәдән китүләр белән чагылдыра. Галим фикеренчә, 1917 елга жәдитчелек хәрәкәте туктатыла диярлек, мәгариф системасын контрольдә тоту дәүләт карамагына күчә һәм дөньяви төс ала.

Н. Исәнбәт жәдитчелеккә каршы булганнар рәтенә Ишми-ишанны (Динмөхәммәтовны) һәм аның фикердәшләрен, донослар язып, пантюркизм белән көрәшү шигаре астында хакимиятне жәдиди мәдрәсәләрне юкка чыгаруга этәргән татар провокатор-карагруһчыларын кертә.

Н. Исәнбәт фикеренчә, реформалар нәтижәсендә жәдиди мәдрәсәләр татар милли интеллигенциясен әзерләү урынына әверелә. Үз китабында ул, С. Кудашка сылтама ясап, «Галия» мәдрәсәсен тәмамлаучылар исемлеген анализлый: “"Галия" мәдрәсәсе 13 ел яшәп (19061919), аны 1500 шәкерт тәмамлаган, шулардан барлыгы 27 кеше мулла булган. Сәйфи үзе белгән 100 кешедән 57 се - КПСС члены, 20 се - профессионал язучы һәм социал реализмчылар, 28 кеше - журналист, фронт газеты редакторлары, 58 е - профессор, доктор һәм кандидат наук, 6 сы - агроном, 3 се -инженер, 3 се - юрист, 4 се - дипломат, 6 сы - татарбашкорт, казакъ республикаларында мәгариф 
министрлары, 2 се - артист, берсе - композитор, калганнары - укытучылар» [Исәнбәт, Мәгърифәт - Жәдид, Б. 39].

Н. Исәнбәт татар жәдитчелеген бәяләгәндә вульгар-социологик формалаштырулар куллануга каршы чыга. Галим жәдитчелеккә каршы куелган күпләгән гаепләмәләрнең урынсыз булуын тикшерә һәм дәлилли:

a) пантюркизм белән бәйләнеше;

Жәдитчелек өчен сәяси проблема булып, аның нигез салучысы - туган иленнән 1944 елда депортацияләнгән һәм 1967 елда гына өлешчә реабилитацияләнгән кырым татары Исмәгыйль Гаспралы шәхесе тора. Сугыштан соңгы чорда СССР жәдитчелекнең бик күп вәкилләре белем алган Төркия белән начар мөнәсәбәттә була.

Татар галиме, бу каршылыклы моментларны урап узарга тырышып, милли мәгариф системасын яңартуның чишмә башында Исмәгыйль Гаспралы түгел, ә, иң беренче чиратта, татар мәгърифәтче-галимнәре $\Gamma$. Курсави, бертуган Хәлфиннар, Ш. Мәржани, К. Насыйри, татар мәдрәсәсенә реформа ясарга жыенган бертуган Фәезхановлар торганлыгына басым ясый [Исәнбәт, Жәдитчелек, Б. 15-16]. Н. Исәнбәт фикеренчә, татар әлифбаларын язучы М. Ишмөхәммәтов белән Г. Баруди «аваз методы»н гамәлгә кертү вакытында, Исмәгыйль Гаспралы әлифбасыннан бигрәк, Европа галимнәре тәжрибәсенә, аерып алганда, К. Д. Ушинский казанышларына нигезләнә. Галим И. Гаспралыны, тел берлеге нигезендә, төркиләрнең берләшүе турында хыялланган «Тәржеман» газетасы мөхәррире буларак характерлый. Галим фикеренчә, татар мәгърифәтчеләре Ш. Мәржани, Х. Фәезханов, К. Насыйри һ.б. 1880 нче еллардан, милли мәгариф системасын рус гимназияләре һәм университетлары үрнәгендә реформалаштыруга юнәлтелгән проектлар тудырып, китаплар нәшер итеп, чынлыкта татаризм идеяләрен чынга ашыралар.

Бербөтен төрки тел тарафдарлары булып, галимнәр фикеренчә, жәдитчеләр түгел, ә үзләрен «мөселманнар» дип атаган кадимчеләр чыгыш ясый [Исәнбәт, Мәгърифәт - Жәдид, Б. 43]. Кадимчеләр Европа уку-укыту системасы белән көрәшәләр, алар Европача белем алуның үзләрен кәферләргә әверелдерүеннән һәм руслаштырудан куркалар [Исәнбәт, Мәгърифәт - Жәдид, Б. 56-61].

б) панисламизмда гаепләү;

Н. Исәнбәт фикеренчә, жәдитчелекнең мәдәни-мәгърифәтчел хәрәкәт буларак меңьеллык тарихы бар, һәм ул 1905 елда төзелгән, алпавытлар hәм эре буржуазия мохитеннән чыккан мөселман кадетларыннан торган, «хәрәкәтләре 1905-1907 нче еллар арасында булган һәм революция куркынычы бетеп реакция жиңүе белән үзе дә беткән» «Мөселман иттифакы» партиясе белән берничек тә бәйле түгел [Исәнбәт, Жәдитчелек, Б. 1718]. Галим ассызыклавынча, 1905 елдан соң жәдитчелек хәрәкәтен социал-демократлар партиясе тарафдарлары Х. Ямашев, Г. Колахмәтов һ.б. контрольдә тота башлый. Алга таба алар төрле партия тарафдарларына әверелә: сул социал-демократлар («уралчылар»), уң социалдемократлар («азатчылар»), эсерлар («таңчылар»). Алдынгы татар яшьләре тарафдарлары, «Ислах» комитеты төзеп, мәдрәсәләр челтәрен контрольдә тота башлыйлар. Шәкертләрнең революцион стачкалары һәм забастовкалары, татар телендәге алдынгы вакытлы («Фикер» газетасы, «Яшен», «Карчыга», «Чүкеч» журналлары) басмалар нәшер итүләре артында нәкъ менә шушы көчләр тора да инде. Н. Исәнбәт фикеренчә, алар «Иттифакъ әл-мөслимин» либераль партиясенә каршы уңышлы көрәш алып баралар [Исәнбәт, Мәгьрифәт-жәдид, Б. 45]. Г.Тукай, М.Гафури, Ф.Әмирхан, Г.Колахмәтов, Г.Ибраһимов кебек үзләрен жәдитчеләр дип игълан иткән язучылар татар реалистик әдәбиятын үстерүгә искиткеч зур өлеш кертә. Н. Исәнбәт жәдитчеләрнең милли басмаларны үстерүдәге ролен ассызыклый. Жәдиди мәктәпләрне тәмамлаучылар Октябрь инкыйлабыннан соң сәяси агитаторлар, Кызыл Армия комиссарлары рәтләрен тулыландырып, фронт газеталары чыгаруда актив катнашалар.

Н. Исәнбәт, татар язучыларының әсәрләрен мисалга китереп, татар жәдитчелегенең панисламизмга бәйлелеген инкяр итә, бу күренешнең аларда кискен тәнкыйтьләнүен күрсәтә (Г. Тукай «Китмибез», «Вакыт»; Г. Ибраһимов «Без татарбыз») һәм нигез салучылары Ш. Мәржани һәм К. Насыйри булган татаризм идеяләренең татар халкы мохитендә алга таба да таралуын дәлилли [Исәнбәт, Мәгърифәт-жәдид, Б. 46]. Татар галиме жәдитчелекнең панисламизм hәм пантюркизм белән бәйләнешен Ишми ишан һәм аның тарафдарлары теләге белән оештырылган суд хөкеме дәлилли алмавына игътибар итә. [Исәнбәт, Мәгърифәт-жәдид, Б. 50].

в) «жәдитчелек - контреволюцион хәрәкәт».

Н. Исәнбәт жәдитчелекне «өстән төшерелгән» ике канатка бүлүгә кискен каршы чыга. 
Б.Г. Гафуров (Гафуров) һәм аның фикердәшләре белән каршылыкка кереп, татар галиме татар жәдитчелеген мәгарифне Европа үрнәге буенча реформалаштыруга һәм татар әдәбиятын һәм мәдәниятен модернизацияләүгә юнәлтелгән мәдәни-агарту хәрәкәте дип саный. Татар галиме фикеренчә, үзенең эчке каршылыгы аркасында, «өстән» төшерелгән «аракчеевщина» концепциясе милли мәгариф системасына сизелерлек зыян китерәчәк, чөнки ул жәдитчелек чорында милли мәдәнияттә хәлләрнең ялган картинасын тудырырга ярдәм итә.

Н. Исәнбәт татар галимнәренең Урта Азия жәдитчелеген анализлаганда кулланыла торган гаепләү «ярлыкларын»ың сукырларча күчермәсенә каршы чыга.

Галим-энциклопедист милли тарихны фальсификацияләүгә һәм үткәннең мәдәни потенциалын игътибарсыз калдыруга каршы чыгыш ясый. Ул шәхес культы чорында жибәрелгән, Ленин милли сәясәтенә каршы килгән идеологик хаталарны жинү зарурлыгына басым ясый.

Н. Исәнбәтнең жәдитчелеккә багышланган мәкаләләре татар тарихындагы мәдәни-мәгърифәти хәрәкәтне өйрәнү өчен мөһим чыганак булып тора. Ул милли интеллигенциянен ижтимагый-мәдәни тормышны либерализацияләүгә юнәлгән өметләрен дәлилли. Булган материалларны анализлап, без шундый фикергә килә алабыз: Н. Исәнбәт жәдитчелек турындагы бәхәсләрнең актив катнашучысы була, ул катгый партия контроле шартларында рәсми кабул ителгән карашларга каршы барырга да курыкмый. Татар энциклопедист галиме Үз мәкаләләрендә жәдитчелек үсеше өчен кирәкле алшартларны карап уза, аның ике этап дәвамындагы үсеш үзенчәлекләрен кыскача анализлый, бу мәдәни-мәгърифәти хәрәкәтнең милли үзенчәлеген ача, жәдитчелекне күренеш буларак дискредитацияләүгә юнәлгән фальсификацияләрне кире кага. Н. Исәнбәтнең жәдитчелек турындагы бәхәсләрдә актив катнашуы аның батыр гражданлык позициясенең чып-чын дәлиле.

\section{Әдәбият}

Госманов М. Аксакаллар мәжлесеннән. Нәкый Исәнбәт (1899-1992) // Госманов М.Г. Хәтер мизгелләре : истәлекләр. Казан: Татар. кит.нәшр., 2019. Б. 174-199.
Ибраһимов $Г$. Бөек остазымызның кайбер тәэлифләре //Аң. 1915. № 1. С. 7-19.

Ибраһимов Г. Бөек остазымызнын тарихы бер тәнкыйде // Аң. 1915. № 2. С. 39-43.

Исәнбәт Н. Мәгърифәт-жәдид // Н. Исәнбәтнең шәхси архивы, кулъязма. 40 б., датасыз. Татар. телендә.

Исәнбәт Н. Жәдидчелек // Н. Исәнбәтнең шәхси архивы, кулъязма. Татар. телендә. 30 б.

Сәгъди Г. Татар әдәбияты тарихы. Казан: Татар. дәүләт нәшр. басмасы, 1926. 300 б.

Таһиров И.Р. Алтын Урда һәм «Идегәй» дастаны // Казан утлары. 1993. №11. Б. 145-147.

Шафиков К. Тарихи чынлык өчен // Совет әдәбияты. 1944. №10. Б.3-8.

Валидов Д. Очерк истории образованности и литературы татар (до революции 1917 г.). Москва; Петроград: Гос. изд-во, 1923. 106 с.

Гайнуллин M.X. Каюм Насыров и просветительское движение среди татар. Казань: Таткнигоиздат, $1955.96 \mathrm{c}$.

Гафуров Б.Г. Успехи национальной политики КПСС и некоторые вопросы интернационального воспитания // Коммунист. 1958. № 11.

Из постановления бюро Татарского обкома ВКП (б) «Об ошибках в учебнике литературы для 8 класса татарских школ» // История татар с древнейших времен: 7 т. - т. 7. Казань: Институт истории Ш. Марджани АН РТ, 2013. С.861-862.

Мухаметов Х.Г. Просветительские идеи в татарской литературе последней четверти XIX века: Автореф. дис. ... канд. филолог. наук. - Казань: КГУ, $1953.17 \mathrm{c}$.

Постановление ЦК ВКПб от 9 августа 1944 г. «О состоянии и мерах улучшения массовополитической и идеологической работы в Татарской партийной оргвнизации»// КПСС в резолюциях и решениях съездов и пленумов ЦК в 16 т. Т.7. (19381945). М.: Политиздат, 1985. С.513-520.

Революция 1905-1907 гг. в национальных районах России [Текст]: Сборник статей / Под ред. Л. М. Иванова [и др.]; Акад. наук СССР. Ин-т истории. Москва: Госполитиздат, 1955. 832 с.

Султанбеков Б. «Идегей», Сталин и наше время // Татарстан. 1992. №7-8. С.32-47.

Фасеев К.Ф. Из истории татарской передовой общественной мысли. (Вторая половина XIX - начало XX в.). Казань: Таткнигоиздат, Ред. полит. и ист. лит., 1955. 280 с.

Хабутдинов А., Хабутдинова М. Образ Наки Исанбета в татарской прозе // Филология и культуpa. PHILOLOGY AND CULTURE. 2019. №4(58). C.191-201.

Хаплехамитов Р.Б. Татарская творческая интеллигенция и власть (1944-1965). Казань: «Слово», 2011. 152 с. 


\section{«ВОПРОС ДЖАДИДИЗМА ЯСЕН, НО ИСАНБЕТ ХОЧЕТ ЗАПУТАТЬ ЕГО ПО-СВОЕМУ ИЗ ИСТОРИИ ДИСКУССИИ О ДЖАДИДИЗМЕ В 1950-1960 ГГ.}

Айдар Юрьевич Хабутдинов, Казанский филиал Российского государственного университета правосудия, Россия, 420088, г. Казань, ул. 2я Азинская, д. 7а, aihabutdinov@mail.ru.

В статье рассматривается концепция джадидизма, изложенная в трудах ученогоэнциклопедиста Наки Исанбета (1899-1992). Материалом исследования послужили статьи писателя, посвященные джадидизму. В 1930-1950-е гг. из-за своих взглядов Н. Исанбет не раз был подвергнут гонениям со стороны властей. Писатель позволил себе открытую критику спущенной сверху концепции джадидизма. Статьи Н. Исанбета о джадидизме - свидетельство надежд национальной интеллигенции на либерализацию общественно-культурной жизни.

Ключевые слова: татарская литература, Н. Исанбет, татарское медресе, мир шакирдов, повседневность. 